\title{
RANGE EXTENSIONS FOR FOUR SMALL MAMMALS IN ALBERTA*
}

HUGH C. SMITH and ROD D. BURNS,

Provincial Museum of Alberta, Edmonton. T5N 0M6

The Provincial Museum of Alberta conducted mammal surveys in eastern and central Alberta during the summer of 1975. A series of small mammals was obtained that expands our knowledge of their distribution in the province.

One survey was conducted along the Alberta-Saskatchewan border from Paradise Valley (Tp47 R2 W4) to Cadogan (Tp37 R3 W4), Alberta, from August 6 to 15. This area is included in Rowe's Aspen Grove section of the Boreal Forest Region. ${ }^{+}$Other surveys were made in the Hand Hills area (Tp29 R17 W4) from August 21 to 26 and in the Wintering Hills area (Tp26 R18 W4) of central Alberta from September 24 to 27. These two areas are included in the Grassland Region. ${ }^{4}$ Specimens of Arctic Shrew (Sorex arcticus), Wandering Shrew (Sorex vagrans), and Gapper's Redbacked Vole (Clethrionomys gapperi) were collected that either extend the range of these mammals or are new locality records for the species.

Arctic Shrew: In a recent review of the distribution of shrews in Alberta, Salt outlined the range of Sorex arcticus as north of the Battle River in eastern Alberta and north of the North Saskatchewan River in western Alberta. ${ }^{\text {It }}$ It is considered to be a characteristic mammal of the Boreal Forest Zone although Banfield suggests "that it may be ...typical of the subclimax or transitional vegetation stages.":3 " " During our survey two Arctic Shrews were trapped, one in what may be termed "typical" habitat, the other in "atypical" habitat. The first, trapped August 7 in the Paradise Valley area (Tp48 R2 W4), was caught in tall grass

*Natural History Contribution Number 32. along a roadway which dissects a parkland slough. The topography of the area was undulating and in many places aspen (Populus tremuloides) occupied low lying areas. The slough was long and narrow with emergent vegetation along the edge. A large stand of aspens was on the south side of the slough and cultivated fields on the north. This area is well within Parkland and the known range of the species. ' is

The second Arctic Shrew was secured in the area south of Cadogan (Tp37 R3 W4). This specimen was trapped in grass bordering a small slough. The area immediately surrounding the slough is pasture land, with the nearest trees approximately $1 / 4$ to $1 / 2$ mile distant. The topography is slightly undulating and the soil is sandy. The specimen, a female weighing 8.8 grams and measuring 111 $\mathrm{mm}$, was caught on August 15. This is an extension of approximately 35 miles south of the Alberta range outlined by Salt."

Wandering Shrew: The distribution of the Wandering Shrew in Alberta is not well known. Findley includes the entire province except for a narrow strip in the northeast." Banfield follows Soper and includes most of northern and western Alberta, the mountains of the southwest, and a narrow strip along the United States border east to Saskatchewan, including the Cypress Hills. ${ }^{6}$ Salt outlines a similar distribution, but includes the entire province north from the North Saskatchewan River, as well a's the mountain regions of the west, and the narrow strip along the United States border." The area south of the North Saskatchewan that includes the Battle, South Saskatchewan, Bow and Oldman 
Rivers, he designates as a region of "occasional and probable", oc. currence.

During our survey of the Hand Hills and the Wintering Hills, four Wandering Shrews were collected. The first was captured on August 23 in the Hand Hills (Tp29 R17 W4). This specimen was trapped on a south facing slope that was covered with grass and young rosebushes (Rosa sp.). There was a stand of aspen about 15 yards from the trap site. The surrounding area was either under cultivation or was pasture with clumps of willows (Salix sp.) and aspen scattered throughout. The specimen, a male, weighed 5.4 grams and measured 105 $\mathrm{mm}$ in total length.

The other three specimens were collected in the Wintering Hills area (Tp26 R18 W4). All were trapped in long grass either on a hillside or at the base of a hill. The trap site was the only area not grazed by livestock. The general area is grassed hills with scattered stands of aspen. Most of the treed and open areas had been grazed by cattle. The specimens, three females, were caught on September 25 and 26. They weighed $4.8,5.0$ and 5.6 grams and measured 106, 111 and $110 \mathrm{~mm}$, respectively, in total length.

Gapper's Red-Backed Vole: Gapper's Red-backed Vole is considered to be a characteristic species of the Boreal Forest community and prefers "forests where mossy rotten logs, stumps, and brush provide cover ....'. ${ }^{3}$ I In Alberta it is distributed through the northern portion of the province south of the North Saskatchewan River and the upper limits of the Red Deer River. It is found in the mountains and in the Cypress Hills ${ }^{1}{ }^{6}$. The distribution is similar to the Wandering Shrew in Alberta.

During the trapping period in the Hand Hills, 7 Red-backed Voles were caught. These animals were trapped in a variety of situations: at the base of saskatoon bushes (Amelanchier alnifolia), in a willow thicket, in an aspen grove, in a willow thicket with little undergrowth, and along the edge of an aspen woods. The series of specimens consisted of 6 males and 1 female. The males ranged in weight from 9.3 to 19.5 grams and 102 to 110 $\mathrm{mm}$ in total length. The female weighed 19.6 grams and was $105 \mathrm{~mm}$. in total length.

Water Shrew: Although not part of the survey conducted by the Provincial Museum of Alberta, a Water Shrew (Sorex palustris) collected by J. Salt on July 25, 1975, in the Wainwright area (Tp40 R6 W4) is worth reporting for it extends the range of this mammal several miles south of its present known range. The specimen, an adult female, weighed 12.9 grams and measured $147.0 \mathrm{~mm}$ in total length.

The Water Shrew in Alberta, as outlined by Salt, is found throughout the northern two thirds of the province south to the Red Deer River in central Alberta and to just across the Battle River in eastern Alberta." The specimen reported here extends this range approximately 40 miles southward.

Discussion: The occurrence of an animal outside its known range may be the result of many factors. First, it may be the occurrence of an animal far outside its normal range as occasionally happens with birds that are blown off their usual migratory routes. Second, it may be an extension of the animal's range due to environmental changes, or third, it may be an artifact of the people working in the area. With mammals, long range extralimital occurrences are extremely unusual except for bats or animals that are transported accidentally or intentionally by man. Whether the range extensions reported here are results of environmental changes or due to more thorough collecting techniques is uncertain at this time and will have to await more extensive field work in the areas concerned.

'BANFIELD, A. W. F. 1974. Mammals of Canada. National Museums of Canada, University of Toronto Press, Toronto. $438 \mathrm{p}$. 
"FINDLEY, J. S. 1955. Speciation of the wandering shrew. University of Kansas, Museum of Natura! History, Lawrence, Kansas. Vol. 9. 68 p.

"KENDEIGH, S. C. 1961. Animal ecology. Prentice-Hall, Inc. Englewood Cliffs, N.J. 468 p.

${ }^{4}$ ROWE, J. S. 1972. Forest regions of Canada. Canadian Forestry Service, Department of the Environment. Information Canada, Ottawa. $172 \mathrm{p}$.

'SALT, J. R. 1975. The Soricidae of Alberta - a review. Unpublished manuscript. Provincial Museum of Alberta.

${ }^{6}$ SOPER, J. D. 1964. Mammals of Alberta. Department of Industry and Development, Queen's Printer, Edmonton. 402 p.

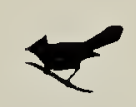

\section{COUGAR SHOT AT CUTKNIFE, SASK.}

\section{By TOM WHITE, 2580 Retallack St., Regina, Sask.}

John Reinboldt went out to check the farm fence at about 9:30 a.m., November 15, 1975, when he saw a cougar moving in long leaps about 250 yards away. It was near the cattle so he went back for his dog and gun. He released his German shepherd which flushed the cougar out of the brush and pursued it for a quarter mile. The cougar would run, pause, look back and then run again. Mr. Reinboldt walked to within 30 yards of where the cougar was facing the dog and shot it. One hundred yards from where the cougar was first sighted, a deer was found with its belly slit open and the shoulder and neck cut. The cougar was obtained by Ken Smith, Conservation Officer at North Battleford, and given to the Museum of Natural History in Regina. It was a female weighing 125 pounds with a body 50 inches from tip of nose to base of tail and a further 27 inches for the tail.

Rabbit tracks in the snow.

Lorne Scott
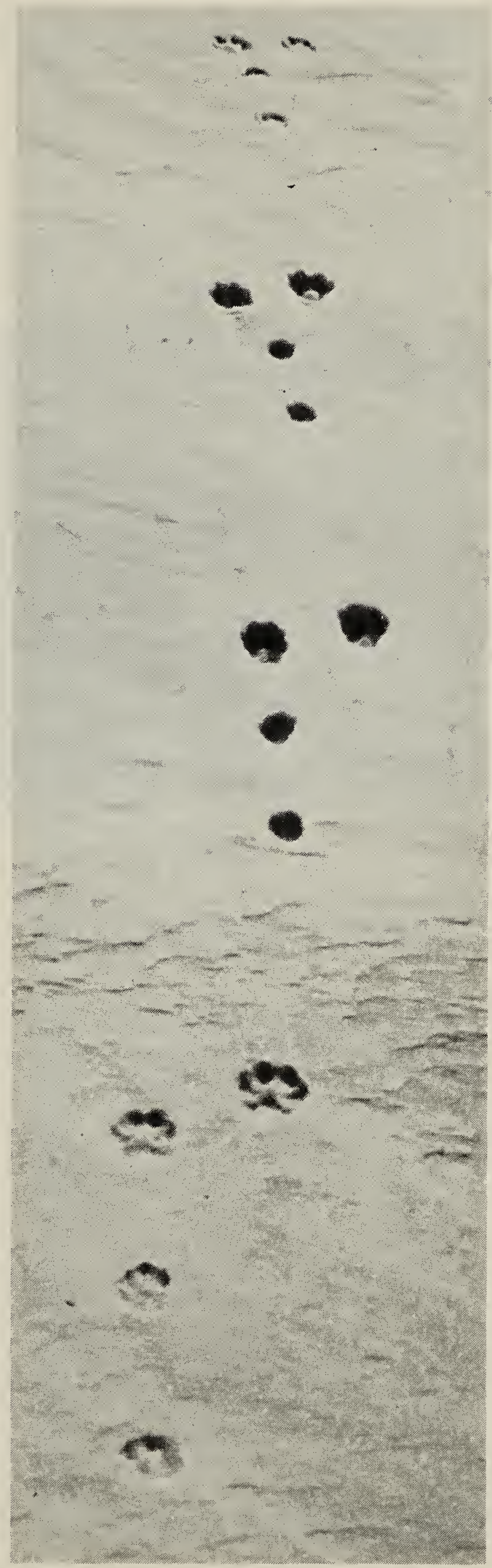